\title{
Soil Quality Analysis of Brackishwater Shrimp Farming in Coastal Areas of Takalar Regency - Indonesia
}

\author{
Muhammad Kasnir \\ Faculty of Fisheries and Marine Science Indonesian of Moslem University \\ Makassar 90230, Indonesia \\ E-mail: kasnir_umi@yahoo.com
}

Harlina

Faculty of Fisheries and Marine Science Indonesian of Moslem University

Makassar 90230, Indonesia

E-mail: linausman1965@yahoo.com

Jayadi

Faculty of Fisheries and Marine Science Indonesian of Moslem University

Makassar 90230, Indonesia

E-mail: jayadi@yahoo.com

Received: Oct. 13, 2014 Accepted: December 23, 2014 Published: December 30, 2014

doi:10.5296/jee.v5i2.7043ＵRL: http://dx.doi.org/10.5296/jee.v5i2.7043

\begin{abstract}
The study aims to find out condition of soil quality in brackishwater ponds in Mangara Bombang Sub-district, Takalar Regency where the center for brackishwater farming development is built. Soil quality sampling used as the main requirements for brackishwater shrimp farming parameter consist of soil texture, $\mathrm{pH}$, organic matter, nutrients and pyrite content. Supporting soil quality parameters in brackishwater shrimp farming are $\mathrm{pH}_{\mathrm{FOX}}$, KTK, Cation $(\mathrm{K}, \mathrm{Ca}, \mathrm{Na}$, and $\mathrm{Mg}$ ), TSA, TAA, and redox. Sampling is then analyzed in laboratory to find out condition of soil parameters in brackishwater areas, Mangara Bombang
\end{abstract}




\section{Macrothink}

coastal areas. Calculation of soil quality including $\mathrm{pH}_{\mathrm{FOX}}, \mathrm{KTK}$, Cation $(\mathrm{K}, \mathrm{Ca}, \mathrm{Na}$, and $\mathrm{Mg}$, TSA, TAA, and redox aims to find out eligibility for brackishwater shrimp farming. The findings indicate that in general, brackishwater soil quality in Mangara Bombang coastal areas, Takalar Regency is at the eligible limits, or the soil is capable of promoting brackishwater shrimp farming.

Keywords: Brackishwater pond, Parameter, Soil quality, Shrimp farming 


\section{Introduction}

Indonesia with $81,000 \mathrm{~km}$ shoreline and 5.6 million $\mathrm{km} 2$ coastal waters has potential to produce fisheries products which are capable of making the people live in prosperous. The coastal waters also create employment for surrounding communities in addition to its potential in marine and beach tourism. Takalar Regency, especially Mangara Bombang Sub-district has potential fishery product to be developed, i.e. brackishwater shrimp farming. This brackishwater shrimp farming has gone on for years and developed to food and bioindustrial activity. It is proved that the business is capable of producing industrial products by means of various technology utilized these days. Along with aquaculture expansion and fishery product demand, shrimp and fish has been developed into coastal aquaculture in early 1980s. Coastal aquaculture, i.e. brackishwater farming, is carried out intensively, and tiger prawn (Penaeus monodon Fab.) is the main commodity. This aquaculture product is especially exported to foreign countries as source of foreign exchange (Tuhri, 2000, Bose, et al., 1991).

Mangara Bombang Sub-district belongs to one of sub-districts in Takalar Regency coastal areas, and this area has potential and fairly developed fishery farming. Therefore, the local government of Takalar Regency defines Mangara Bombang Sub-district coastal areas as one of central regions for fish farming development. Fish farming activities which have been developed therein are seaweed cultivation and brackishwater shrimp cultivation. Size of brackishwater pond in Mangara Bombang coastal areas is 863,097 ha. A size of 35,98 ha is managed by in;ensive technology and 827,117 ha is managed by traditional technology (Department of Marine and Fisheries, Takalar Regency, 2008).

Soil quality is the requirement having important role in determining good or poor soil quality. Soil for brackishwater land then influences the success of brackishwater farming because the land is capable of not only holding the water back, but also providing various nutrients as natural feed for the cultivated shrimp (Boyd, 1995, Soewardi, 2002). Soil quality parameters used as minimum requirements for brackishwater shrimp cultivation are soil texture, $\mathrm{pH}$, organic matter content, nutrients and pyrite content. Further supporting soil quality parameters for brackishwater shrimp cultivation are $\mathrm{pH}_{\mathrm{FOX}}, \mathrm{KTK}$, Cation $(\mathrm{K}, \mathrm{Ca}, \mathrm{Na}$, and Mg), TSA, TAA, and redox (Dent, 1986; Widigdo, 2002; Mustafa et al. (2004).

The existing brackishwater shrimp cultivation activity in Mangara Bombang Sub-district coastal areas shall have data about soil quality that allow shrimp farming to operate continuously. Purposely, the study aims at finding out condition of soil quality in shrimp brackishwater pond in Mangara Bombang Sub-district. Expectedly, the findings can be beneficial for aquaculturist in Mangara Bombang Sub-district and the government as a reference for shrimp brackishwater pond management and planning.

This study aims to find out condition of soil quality for brackishwater ponds development in Takalar Regency coastal areas. Hopefully, the study will get into head in formulating policy for brackishwater development in Takalar Regency. 


\section{Research Methodology}

\subsection{Research Site and Time}

The study is conducted in brackishwater areas in Mangara Bombang coastal areas, Takalar Regency from June, 2010 to July, 2010. Based on UTM zone, the site is between $\mathrm{x}=768117$ : $\mathrm{Y}=9385750$ and $\mathrm{x}=770926 ; \mathrm{Y}=9381886 \quad$ (Halder, 2013).

\subsection{Research Implementation Methodology}

There are two types of data used in this study: primary and secondary data. Primary data is collected through observation/direct measurement at research site Akbarzadeh and Mehrjardi, 2010), while the secondary data is collected through literature-retrieval system existing in various related government agencies and private organization, such as Department of Marine and Fisheries of Takalar Regency, Regional Development Planning Agency, and brackishwater farmer. The primary data observed in this study consists of Some soil quality parameters constituting key parameters for the success of shrimp farming

Observation and sampling on the soil quality is conducted directly (in situ). Soil sampling is selected in brackishwater areas in depth of 0-20 cm (Ahern, et al., 2004; Mustafa et al., 2004). Sampling is taken from 14 stations (sampling in 1 station has 3 brackishwater sections where every 1 sampling point is in the center of brackishwater pond). Then, total brackishwater sections to which the sample is selected are 42 sections. Besides, direct measurement is also conducted in the field, then the sample is analyzed in laboratory (Soil Survey Staff, 2001).. Data collection of the observed soil quality parameters, analyzer/method of analysis and place of measurement are presented in Table 1.

Table 1. Soil quality parameters, instrument/method of analysis and place of measurement

\begin{tabular}{|c|c|}
\hline Parameter & Method of Analyzer \\
\hline Soil Texture & Bouyoucos hydrometer \\
\hline Cation-exchange Capacity & Colorimetry \\
\hline Pyrite & Ahern \\
\hline Soil pH and redox & Redox meter \\
\hline $\begin{array}{c}\text { Total Potential Acidity and Total Actual } \\
\text { Acidity (TPA and TAA) }\end{array}$ & Ahern's Scientific Method \\
\hline $\mathrm{K}, \mathrm{Ca}, \mathrm{Na}$, and $\mathrm{Mg}$ & $\mathrm{K}, \mathrm{Ca}, \mathrm{Na}$, and Mg \\
\hline $\mathrm{N}-$ total & Kjeldahl method \\
\hline Phosphor $\left(\mathrm{P}_{2} \mathrm{O}_{5}\right)$ & Spectrophotometer \\
\hline
\end{tabular}

\section{Findings and Discussion}

Soil quality is the requirement holding crucial role which determines good or poor soil quality where brackishwater land will be used to cultivate shrimp (FAO1998; Agus, et al, 2006). Good soil quality is capable of not only holding the water back, but also providing various nutrients as natural feed for the cultivated shrimp. Soil quality parameters used as the minimum requirement for brackishwater shrimp cultivation are soil texture, $\mathrm{pH}$, organic matter content, nutrients and pyrite content. Supporting soil quality parameters for brackishwater shrimp farming are $\mathrm{pH}_{\mathrm{FOX}}, \mathrm{KTK}$, Cation (K, Ca, Na, and $\mathrm{Mg}$ ), TSA, TAA, and redox (Ahern, et al, 2004; Ahern, et al, 1998a, 1998 b, 1998c).. Soil quality parameter value 
is made in list in Table 2.

Table 2. Analysis Results of Soil Quality Parameter

\begin{tabular}{|c|c|c|c|}
\hline Parameter & Unit & $\begin{array}{l}\text { Result of Soil Quality } \\
\text { Parameter }\end{array}$ & $\begin{array}{c}\text { Recommended }_{*)} \\
\text { Rents }\end{array}$ \\
\hline $\begin{array}{l}\text { Soil Texture } \\
\text { a. Sand } \\
\text { b. Clay } \\
\text { c. Dust }\end{array}$ & $\begin{array}{l}\% \\
\% \\
\%\end{array}$ & $\begin{array}{c}60.65 \pm 12.22 \\
(41.00-89.00) \\
14.75 \pm 13.33 \\
(0.00-45.00) \\
24.55 \pm 10.50 \\
(10.00-47.00)\end{array}$ & $\begin{array}{l}- \\
- \\
-\end{array}$ \\
\hline $\begin{array}{l}\text { Cation-exchange } \\
\text { Capacity (CEC) }\end{array}$ & $\mathrm{me} / 100 \mathrm{~g}$ & $\begin{array}{l}30.54 \pm 15.09 \\
(9.34-75.65)\end{array}$ & $>20 \mathrm{me} / 100 \mathrm{~g}$ \\
\hline Pyrite & $\%$ & $\begin{array}{c}0.52 \pm 0.63 \\
(0.00-1.94)\end{array}$ & $<2 \%$ \\
\hline $\begin{array}{l}\text { Degree of Acidity } \\
\mathrm{pH}_{\mathrm{F}}\left(\mathrm{H}_{2} \mathrm{O}\right)\end{array}$ & - & $\begin{array}{c}7.33 \pm 0.34 \\
(6.42-8.11)\end{array}$ & $5-6.5$ \\
\hline $\mathrm{pH}_{\mathrm{FOX}}$ & - & $\begin{array}{c}4.94 \pm 2.23 \\
(1.41-8.33)\end{array}$ & - \\
\hline Organic carbon & $\%$ & $\begin{array}{c}3.85 \pm 4.43 \\
(0.33-18.52)\end{array}$ & $4-20 \%)$ \\
\hline TPA & $\mathrm{mol} \mathrm{H}^{+} /$th & $\begin{array}{c}173.42 \pm 235.64 \\
(0.00-771.30)\end{array}$ & $\begin{array}{l}<600 \mathrm{moh} \\
\mathrm{H}^{+} / \text {tonne }\end{array}$ \\
\hline TAA & $\mathrm{mol} \mathrm{H}^{+} /$th & $\begin{array}{c}2.35 \pm 7.53 \\
(0.00-41.00)\end{array}$ & $<40 \mathrm{H}^{+} /$one \\
\hline Redox & $\mathrm{meV}$ & $\begin{array}{c}-160.75 \pm 120.63 \\
(-376)-(-3.01)\end{array}$ & $\begin{array}{l}+10 \mathrm{meV}(-) \\
+50 \mathrm{meV}\end{array}$ \\
\hline $\begin{array}{l}\text { Macronutrients } \\
\mathrm{K}\end{array}$ & $\mathrm{me} / 100 \mathrm{~g}$ & $\begin{array}{c}3.71 \pm 2.28 \\
(0.03-7.77)\end{array}$ & $\begin{array}{c}0.5-1.0 \mathrm{me} / 100 \\
\mathrm{~g} \\
(>500 \mathrm{mg} / \mathrm{l})\end{array}$ \\
\hline $\mathrm{Ca}$ & $\mathrm{me} / 100 \mathrm{~g}$ & $\begin{array}{l}32.60 \pm 25.78 \\
(2.95-89.46)\end{array}$ & $\begin{array}{l}5.0-20.0 \\
\mathrm{me} / 100 \mathrm{~g}\end{array}$ \\
\hline $\mathrm{Na}$ & $\mathrm{me} / 100 \mathrm{~g}$ & $\begin{array}{l}38.22 \pm 37.14 \\
(3.95-148.65)\end{array}$ & $(>1,200 \mathrm{mg} / \mathrm{l})$ \\
\hline $\mathrm{Mg}$ & $\mathrm{me} / 100 \mathrm{~g}$ & $\begin{array}{l}22.44 \pm 13.53 \\
(4.67-67.14)\end{array}$ & $\mathrm{g}$ \\
\hline & & & $\begin{array}{c}1.0-8.0 \mathrm{me} / 100 \\
\mathrm{~g} \\
(>500 \mathrm{mg} / \mathrm{l})\end{array}$ \\
\hline $\mathrm{N}-$ Total & $\%$ & $\begin{array}{c}0.21 \pm 0.19 \\
(0.00-0.75)\end{array}$ & $0.4-0.75$ \\
\hline Phosphor $\left(\mathrm{P}_{2} \mathrm{O}_{5}\right)$ & $\mathrm{mg} / \mathrm{l}$ & $\begin{array}{c}188.03 \pm 155.84 \\
(0.00-546.76)\end{array}$ & $30-60 \mathrm{mg} / \mathrm{l}$ \\
\hline
\end{tabular}

*) Boyd and Musig, 1992; Baliao, 2000; Taslihan et al., 2003; Poernomo, 1992; Widigdo, 2002; Taslihan et al., 2003; Mustafa et al., 2004

According to the analysis result in Table 2, below is explanation of every parameter: 


\subsection{Soil Texture}

Brackishwater soil particles in Mangara Bombang Sub-district coastal areas are a composite of sand particle from 41.00 to $89.00 \%(60.65 \pm 12.22)$, dust particle from 10.00 to $47.00 \%$ $(24.55 \pm 10.50)$, and clay particle from 0.00 to $45.00 \%(14.75 \pm 13.33)$.

Based on the analysis result of soil structure regarding soil sodicity ratio at SAR (Sodium Adsorption Ratio) equation $=\mathrm{Na}^{+} \times\left[0.5\left(\mathrm{Ca}^{2+}+\mathrm{Mg}^{2+}\right)\right]^{-0.5}=\mathrm{X}$ me. $1^{-1}$, SAR ratio is 7.37 me. $1^{-1}$. This value represents brackishwater soil structure in Mangara Bombang Sub-district coastal areas that belongs to sodic soil phase structure (Menon, 1973; Melville, 1993; Ahern, 1998) In sodic soil phase, high concentration of natrium ( $\mathrm{Na}$ ) in complex soil adsorption can cause soil structure damage. Further implication is that soil aggregate constituting soil internal cohesive force will be weak and have an effect on perishable soil (Ahern, 1998; Sulaeman, et al., 2005)).

Brackishwater construction and irrigation canal can still be built on such soil structure condition under condition that the brackishwater pond embankment and irrigation canal shall be made wider than the pond bottom (Mustafa and Rachmansyah, 2008; Afrianto and Liviawaty, 1991; Taslihan et al., 2003). Besides, the pond shall install brackishwater pond embankment, for example by installing bamboo lath or cement wall inside and outside of the brackishwater embankment. This brackishwater embankment reinforcement aims to lengthen useful life. In traditional brackishwater pond, brackishwater embankment construction reinforcement can be installed by mangrove planting inside and outside the pond embankment and irrigation canal. Strong root system owned by mangrove is expectedly can strengthen the embankment construction and irrigation canal in purpose to make the pond imperishable.

\subsection{Cation-exchange Capacity (CEC)}

Cation-exchange capacity is important for brackishwater shrimp farming since it determines soil capacity in absorbing electrolytes, like $\mathrm{NH}_{4}$, sulfide, and other toxic substances that can endanger the cultivated organism. Calculation of cation-exchange capacity (CEC) to the brackishwater soil is from 9.34 to $75.65 \mathrm{me} / 100 \mathrm{~g}(30.54 \pm 15.09)$. Cation-exchange capacity (CEC) of brackishwater soil in Mangara Bombang Sub-district coastal areas is fairly good for brackishwater shrimp farming according to the recommended value, i.e. $>20 \mathrm{me} / 100 \mathrm{~g}$ (Poernomo, 1992; Widigdo, 2002, Gong, et al., 2012).).

\subsection{Pyritic Soil Content}

Pyrite is composed of iron and soil organic material, and also sulphate which is changed into sulfide by microbe (Pantjara and Sahib, 2008). This pyrite content is extreme factor that can endanger the cultivated organism (Poernomo, 1992). Calculation of pyrite content in brackishwater soil is between 0.00 and $1.94 \%(0.52 \pm 0.63)$. Such value is appropriate for brackishwater shrimp farming and equal with the recommended value, i.e. $<2 \%$ (Poernomo, 1992; Ahern et al,1998, Widigdo, 2002,). High pyrite content has the potential to increase $\mathrm{Fe}^{2+}$ and $\mathrm{SO}_{4}{ }^{=}$and acidify the water of pond (ASSMAC, 1998,.Pantjara and Sahib, 2008; Mustafa and Rachmansyah, 2008). 


\subsection{Degree of Soil Acidity}

Productive soil intended for brackishwater pond shall have neutral to acid $\mathrm{pH}$ where such soil has nutrient and salt in abundance that can stimulate the growth of natural feed. Soil $\mathrm{pH}$ affects water fertility in the pond because $\mathrm{pH}$ defines nutrient solubility in the water (Ahern, and Rayment, 1998d, Widigdo, 2002,). Below is the analysis result of every soil quality:

Direct measurement in the field found that $\mathrm{pH}_{\mathrm{F}}\left(\mathrm{H}_{2} \mathrm{O}\right)$ value is quite high by $7.33 \pm 0.34$ (6.41 - 8.11). It represents that soil acidity in an active brackishwater soil is relatively low during the measurement. When the oxidation is done with peroxide solution $\left(\mathrm{H}_{2} \mathrm{O}_{2}\right)$ at concentration $30 \%, \mathrm{pH}$ value is decreasing incisively up to 1.41 . It informs us that there is still potential acidity held by brackishwater soil particles. It can come into existence suddenly if it is driven by natural condition. Acidity in the soil can also be triggered by the treatment given by brackishwater farmer or cultivator, especially during drying cycle and soil turnover. Accordingly, it is necessary to conduct calcification and soil washing to reduce soil acidity.

Based on measurement result of $\mathrm{pH}_{\mathrm{F}}\left(\mathrm{H}_{2} \mathrm{O}\right)$ parameter, the value indicates that brackishwater soil value is suitable for brackishwater shrimp farming in conformity with the recommended value between 5.0 to 8.5 (Boyd and Musig, 1992; Baliao, 2000; Taslihan et al., 2003). Brackishwater soil with $\mathrm{pH}$ value between 5.0 and 8.5 is categorized by Karthik et al., (2005) as slight since soil $\mathrm{pH}$ is good and inhibitory factor is easily handled (Pantjara and Sahib, 2008).

\subsection{Organic Content (Soil Organic Carbon)}

According to $\mathrm{C}$ organic content measurement result of the brackishwater soil in Mangara Bombang coastal areas, the content ranges from 0.33-18.52\% (3.85 \pm 4.43$)$. Organic matter content within the brackishwater soil is suitable for shrimp farming according to feasibility criteria as the recommended value 4.0-20.0\% (Poernomo, 1992; Widigdo, 2002). The brackishwater soil containing low organic matter content needs additional fertilizer, and conversely, if the soil has suitable organic matter content, it does not need additional fertilizer. The existence of soil organic matter can increase cation exchange capacity (CEC) in addition to its capacity to absorb acid (Soepardi, 1983; Hanafiah, 2004). Organic matter content held within the soil highly affects the growth of algae in the pond bottom because the matter is source of nitrogen for algae. Over-organic matter content within the soil can endanger the cultivated commodity which is caused by decomposition process. During the process, decomposition of dead algae in pond bottom takes oxygen and gives out toxic gas like $\mathrm{CO}_{2}$, $\mathrm{H}_{2} \mathrm{~S}$, and $\mathrm{NH}_{3}$ (Boyd, 1995; Colt and Armstrong, 1981;Camargo, et al., 2005, Boyd, 2008).

\subsection{Total Potential Acidity (TPA) of the Soil}

Total potential acidity (TPA) which is suitable for brackishwater shrimp farming is $<600$ moh $\mathrm{H}^{+} /$ton (Mustafa et al., 2004), and the measurement result finds that Total potential acidity (TPA) in brackishwater soil ranges from 0.00 to 771.30 (173.42 \pm 235.64$)$. Accordingly, total potential acidity of the soil in Mangara Bombang Sub-district coastal areas is mostly at the limit qualified for shrimp farming Gaviria, et al., 1986).. 
But it still, there are ponds with high total potential acidity since the soil sample is collected from mangrove forest which had been converted into brackishwater pond. For those brackishwater ponds which formerly were mangrove lands, remediation (calcification) is applied to neutralize total potential acidity (Cook, et al., 1984).. Amount of lime required is estimated by Ahern's approach (1998) proposing that 1 mol $\mathrm{CaCO}_{3}$ will neutralize $2 \mathrm{~mol} \mathrm{H}^{+}$ $\left(1 \mathrm{~mol} \mathrm{CaCO}_{3}=100.0872 \mathrm{~g}\right.$ ), $1 \mathrm{~mol} \mathrm{H}_{2} \mathrm{SO}_{4}$ is equivalent to $2 \mathrm{~mol} \mathrm{H}^{+}$; accordingly, 1 part of $\mathrm{CaCO}_{3}=1$ part of $\mathrm{H}_{2} \mathrm{SO}_{4}$ (weight). If the average Total potential acidity (TPA) is $173.41-$ $234.10 \mathrm{~mol} \mathrm{H}^{+} /$ton, it will need $86.71-117.05 \mathrm{~mol} \mathrm{CaCO}_{3}$ or $8.67-11.70 \mathrm{~kg} \mathrm{CaCO}_{3}$ to neutralize 1 ton brackishwater soil at average.

\subsection{Total Actual Acidity (TAA)}

Total Actual Acidity (TAA) in brackishwater soil is varied from $0.00-41.00(2.35 \pm 7.53) \mathrm{mol}$ $\mathrm{H}^{+} /$ton. Total Actual Acidity (TAA) in brackishwater soil is suitable for shrimp farming if it is $<40 \mathrm{H}^{+}$/ton (Grant, 1973, Mustafa et al., 2004). Accordingly, total actual acidity of the soil in Mangara Bombang Sub-district coastal areas is mostly at the limit qualified for shrimp farming.

\subsection{Redox Potential of Soil}

Increasing redox potential of soil is affected by the atmospheric $\mathrm{O}_{2}$ penetrating into the soil. $\mathrm{O}_{2}$ is formerly reduced, then it is re-reduced that produces $\mathrm{H}^{+}$and becomes soil acidity source (Conyers, et al., 2003, Simpson and Pedini, 1985 as referred in Hanafiah, 2005).

Calculation of redox potential of soil is ranging from (376) to (3.01) meV (-160.75 \pm 120.63$)$. Value of redox potential in intensive brackishwater pond is fairly good for brackishwater shrimp farming, while value of this redox potential in traditional pond is quite low. The recommended valur of redox potential for shrimp farming shall be $+10 \mathrm{meV}(-)+50 \mathrm{meV}$ (Taslihan et al., 2003; Widigdo, 2002). In intensive brackishwater pond, drying and soil treatment processes is managed well, while both processes is not executed maximally in most traditional brackishwater ponds. Consequently, traditional ponds are still soaked in water. The soaked soil usually fills soil pore spaces with water, thus deficiency in oxygen and soil tends to be reductive. If this condition goes on and on, it will produce ferro iron, sulfide, $\mathrm{CO}_{2}$ and organic acid that can poison the cultivated shrimp.

\subsection{Soil Macronutrients}

Kalium (K)

Macronutrients availability like $\mathrm{K}, \mathrm{Ca}, \mathrm{Na}$ and $\mathrm{Mg}$ within the soil constitutes soil fertility indicators. Main source of Kalium $(\mathrm{K})$ made in the sea water penetrates into brackishwater pond by the time high water occurs. Kalium $(\mathrm{K})$ within the soil can be absorbed by algae living at the pond bottom in form of $\mathrm{K}^{+}$. Main function of this Kalium $(\mathrm{K})$ is to produce carbohydrate and chlorophyll for the algae at the pond bottom. Kalium (K) content within the brackishwater soil can be employed to predict productivity of algae at the pond bottom. Calculation of Kalium (K) content in the brackishwater soil ranges from 0.03 to $7.77 \mathrm{me} / 100$ $\mathrm{g}(3.71 \pm 2.28)$. Value of Kalium $(\mathrm{K})$ held within the the brackishwater soil is quite high for 
shrimp farming, while the suitable value shall be between 0.5 and $1.0 \mathrm{me} / 100 \mathrm{~g}$ (> $500 \mathrm{mg} / \mathrm{l})$ (Boyd, et al., 2002, .Widigdo, 2002; Hasnawi and Mustafa, 2010).).

\section{Calcium $(\mathrm{Ca})$}

Calcium $(\mathrm{Ca})$ availability will directly affect shrimp quality and moulting process living in the pond. This Calcium (Ca) element will be utilized by algae of pond bottom in $\mathrm{Ca}^{++}$. Calculation of Calcium (Ca) content held within the soil ranges from 2.95 to $89.46 \mathrm{me} / 100 \mathrm{~g}$ $(32.60 \pm 25.78)$. Accordingly, the value for brackishwater shrimp farming is higher than the expected value ranging from 5.0 to $20.0 \mathrm{me} / 100 \mathrm{~g}$ ( >1.200 mg/l) (Poernomo, 1992; Widigdo, 2002).

\section{Natrium (Na)}

Increasing Natrium (Na) element in the soil can change brackishwater soil structure and affect the growth of the cultivated commodity (Giap et al., 2005). According to the calculation of Natrium $(\mathrm{Na})$ content held within the brackishwater soil, the value ranges from 3.95 to $148.65 \mathrm{me} / 100 \mathrm{~g}(38.22 \pm 37.14)$. The value is quite high for brackishwater shrimp farming, while the recommended value shall be between 0.7 and $1.0 \mathrm{me} / 100 \mathrm{~g}$. (Poernomo, 1992; Widigdo, 2002).

\section{Magnesium (Mg)}

According to macronutrient analysis result, Magnesium $(\mathrm{Mg})$ is ranging from 4.67 to 67.14 me/100g (22.44 \pm 13.53). Such Magnesium element value for brackishwater shrimp farming

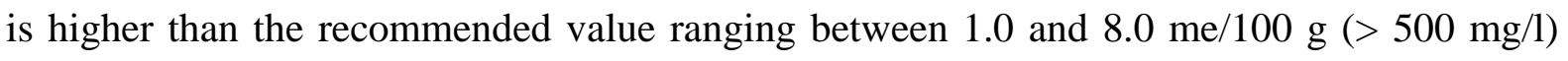
(Poernomo, 1992 ;Widigdo, 2002).

\subsection{Nitrogen ( $N$-Total)}

Nitrogen content constitutes one of brackishwater soil fertility signs; meaning that the higher nitrogen content, the faster growth of algae at the pond bottom (Soepardi, 1983; Effendi, 2003; Hanafiah, 2004). Calculation of nitrogen content (N-total) held within the brackishwater soil ranges from 0.00 to $0.75 \%(0.21 \pm 0.19)$. Nitrogen ( $\mathrm{N}$-total) content in the brackishwater soil is considered as low or less fertile. The value is lower than the recommended value 0.40-0.70\% (Poernomo, 1992; Widigdo, 2002, Anuar, et al., 2008).). Accordingly, soil treatment is still necessary as well fertilization to increase nitrogen (N-total) content in soil Hazelton, and Murphy, 2009).

\subsection{Phosphor $\left(\mathrm{P}_{2} \mathrm{O}_{5}\right)$}

The analysis result of phosphor $\left(\mathrm{P}_{2} \mathrm{O}_{5}\right)$ content held within the brackishwater soil ranges from 0.00 to $546.76 \mathrm{mg} / \mathrm{l}(180.03 \pm 152.84)$. Accordingly, phosphor $\left(\mathrm{P}_{2} \mathrm{O}_{5}\right)$ content in brackishwater ponds of Takalar Regency coastal areas, especially in Mangara Bombang Sub-district, is quite high. Suitable phosphor content shall range from 30 to $60 \mathrm{mg} / \mathrm{l}$. By having such condition, phosphate availability in brackishwater pond is higher than $60 \mathrm{mg} / \mathrm{l}$, and it is considered as slight or suitable, and limit factors is easily handled (Hajek, and Boyd, 1994; Chen and Chin 1998; Karthik et al., 2005). 


\section{Conclusion and Suggestion}

\subsection{Conclusion}

In general, the analysis result of soil quality parameters for brackishwater ponds in Takalar Regency coastal areas, especially in Mangara Bombang Sub-district is highly qualified to promote brackishwater shrimp farming in conformity with soil quality criteria (Poernomo, 1992; Boyd and Musig, 1992; Ilyas et al., 1997; Baliao, 2000; Widigdo, 2002; Taslihat et al. 2003; Mustafa et al. 2004)

\subsection{Suggestion}

It needs further research on suitability and carrying capacity for shrimp farming development in Takalar Regency coastal areas.

\section{References}

Afrianto, E. L. (1991). Teknik pembuatan tambak udang. Kanisius. Bandung

Agus, Y. F., \& Sutono. (2006). Determination of soil texture. In Kurnia, U., Agus, F., Adimihardja, A., \& Dariah, A. (Eds.), Soil Physical Properties and Methods of Analysis (pp. 43-62). Center for Agricultural Land Resources Research and Development, Bogor.

Ahern, C. R., \& McElnea, A. (2004). Calculated sulfur parameters. In: Acid Sulfate Soils Laboratory Methods Guidelines. Queensland Department of Natural Resources, Mines and Energy, Indooroopilly, Queensland, Australia, pp. B11-1-B11-2.

Ahern, C. R., \& Rayment, G. E. (1998d). Codes for acid sulfate soils analytical methods. In: Ahern, C.R., Blunden, B. and Stone, Y. (eds.), Acid Sulfate Soils Laboratory Methods Guidelines. Acid Sulfate Soil Management Advisory Committee, Wollongbar, NSW. pp. 3.1-3.5.

Ahern, C. R., Blunden, B., Stone, Y. N. (1998). Acid sulfate soils laboratory methods. Acid Sulfate Soil Management Advisory Committee, Wollongbar, NSW, Australia.

Ahern, C. R., Blunden, B., Sullivan, L. A., \& McElnea, A. E. (2004). Soil sampling, handling, preparation and storage for analisys of dried samples. In: Acid Sulfate Soils Laboratory Methods Guidelines. Queensland Department of Natural Resources, Mines and Energy, Indooroopilly, Queensland, Australia, pp. B1-1-B1-5.

Ahern, C. R., McElnea, A., \& Baker, D. E. (1998a). Acid neutralizing capacity methods. In Ahern, C.R., Blunden, B., \& Stone, Y. (Eds.), Acid Sulfate Soils Laboratory Methods Guidelines. Acid Sulfate Soil Management Advisory Committee, Wollongbar, NSW, pp. 6.1-6.4.

Ahern, C. R., McElnea, A., \& Baker, D. E. (1998b). Peroxide oxidation combined acidity and sulfate. In: Ahern, C.R., Blunden, B. and Stone, Y. (eds.), Acid Sulfate Soils Laboratory Methods Guidelines. Acid Sulfate Soil Management Advisory Committee, Wollongbar, NSW. pp. 4.1-4.17. 
Ahern, C. R., McElnea, A., \& Baker, D. E. (1998c). Total oxidisable sulfur. In Ahern, C. R., Blunden, B., \& Stone, Y. (Eds.), Acid Sulfate Soils Laboratory Methods Guidelines. Acid Sulfate Soil Management Advisory Committee, Wollongbar, NSW. pp. 5.1-5.7.

Akbarzadeh, A., \& Mehrjardi, R. T. (2010). Spatial distribution of some soil properties, using geostatistical methods in Khezrabad Region (Yazd) of Iran. ProEnvironment, 3, 100-109.

Anuar, A. R., Goh, K. J., Heoh, T. B., \& Ahmed, O. H. (2008). Spatial variability of soil inorganic $\mathrm{N}$ in a mature oil palm plantation in Sabah, Malaysia. American Journal of Applied Sciences, 5(9), 1239-1246. http://dx.doi.org/10.3844/ajassp.2008.1239.1246

ASSMAC (Acid Sulfate Soil Management Advisory Committee). (1998). Acid sulfate soil management guidelines. In Ahern, C.R., Blunden, B., \& Stone, Y. Eds.), Acid Sulfate Soils Laboratory Methods Guidelines. Acid Sulfate Soil Management Advisory Committee, Wollongbar, NSW. p. III.1-28.

Balio, D. D., Rodrigues, E. M., \& Georochi, D. D. (1981). Culture of mud crab Scylla serrata (Forskal) at different stocking densities in brackishwater pond SEAFDEC quar. Res. Report, $5,10-14$.

Bose, A. N., Ghosh, S. N., Yang, C. T., \& Mitra, A. (1991). Coastal Aquaculture Engineering. Oxford \& IBH Publishing Co. Pvt. Ltd., New Delhi. 365 pp.

Boyd, C. E. (1990). Water quality in ponds for aquaculture. Alabama Agricultural Experiment Station. Auburn University, Alabama, 482p.

Boyd, C. E. (1995). Bottom Soils, Sediment, and Pond Aquaculture. Chapman and Hall, New York. 348 pp. http://dx.doi.org/10.1007/978-1-4615-1785-6

Boyd, C. E. (1998). Pond water aerations systems. Journal of Aquaculture Engineering, 18, 9- 20. http://dx.doi.org/10.1016/S0144-8609(98)00019-3

Boyd, C. E. (2008). Pond bottom soil analyses. Global Aquaculture Advocate.

Boyd, C. E., \& Musig, Y. (1992). Shrimp pond effluents: Observations of the nature of the problem on commercial farms. Proceeding of the special session on shrimp farming. Edited by J. Wyban. World aquaculture society, Baton rouge, LA. USA 195 - 197.

Boyd, C. E., Wood, C. W., \& Thunjai, T. (2002). Aquaculture Pond Bottom Soil Quality Management. Pond Dynamics/Aquaculture Collaborative Research Support Program Oregon State University, Corvallis, Oregon. 41 pp.

Buringh, P. (1983). Pengantar pengkajian tanah - tanah wilayah tropika dan sub tropika. UGM Press. Yogyakarta.

Camargo, J. A., Alonso, A., \& Salamanca, A. (2005). Nitrate toxicity to aquatic animals: a review with new data for freshwater invertebrates. Chemosphere, 58, 1255-1267. http://dx.doi.org/10.1016/j.chemosphere.2004.10.044 


\section{Al Macrothink}

Journal of Environment and Ecology ISSN 2157-6092 2014, Vol. 5, No. 2

Chen, J. C., \& Chin, T. C. (1998). Joint action of ammonia and nitrite on tiger prawn, Penaeus monodon, postlarvae. Journal of World Aquaculture Society, 19, 143-148. http://dx.doi.org/10.1111/j.1749-7345.1988.tb00942.x

Cholik, F., Anwar, Z. I., \& Sutartamat, T. (1998). Bertambak udang yang sehat . Prosiding seminar teknologi perikanan pantai. Bali 6-7 Agustus 1998. Pusat Penelitian dan Pengembangan Perikanan Pantai-JICA. Denpasar - Bali.

Colt, J. E., \& Armstrong, D. A. (1981). Nitrogen toxicity to crustaceans, fish, and molluscs. In: L.J. Allen and E.C. Kinney (eds.), Proceedings of the Bio-engineering Symposium for Fish Culture. American Fisheries Society, Bethesda, MD. pp. 34-37.

Conyers, M. K., Heenan, D. P., McGhie, W. J., \& Poile, G. P. (2003). Amelioration of acidity with time by limestone under contrasting tillage. Soil \& Tillage Research, 72, 85-94. http://dx.doi.org/10.1016/S0167-1987(03)00064-3

Cook, H. L., Pongsuwana, U., \& Wechasitt, S. (1984). Recommendations for construction and management of brackishwater aquaculture ponds in areas with acid sulfate soils. In: Malaysia Coastal Aquaculture Development. FI:DP/MAL/77/008, Field Document, 2:243-260.

Dent, D. (1986). Acid Sulphate Soils: A Baseline for Research and Development. ILRI Publication 39. International Institute for Land Reclamation and Improvement, Wageningen. 204 pp.

Dinas Perikanan dan Kelautan Kabupaten Takalar. (2008). Laporan tahunan Dinas Perikanan dan Kelautan, Kabaupaten Takalar.

Dinas Perikanan dan Kelautan Kabupaten Takalar. (2008). Rencana program pengembangan perikanan budidaya di wilayah pesisir Kab. Takalar.

Dinas Perikanan dan Kelautan Provinsi Sulawesi Selatan. (2007). Laporan Tahunan Dinas Perikanan dan Kelautan.

FAO (Food and Agriculture Organization). (1998). Land quality indicators and their use in sustainable agriculture and rural development. In: FAO Land and Water Bulletin 5. FAO, UNDP, UNEP and World Bank, Rome. 208 pp.

Gaviria, M.J.I., Schmittou, H.R. \& Grover, J.H. (1986). Acid sulfate soils: identification, formation and implications for aquaculture. Journal Aquaculture Tropics, 1, 99-109.

Gong, J., Liu, Y., \& Chen, W. (2012). Land suitability evaluation for development using a matter-element model: a case study in Zengcheng, Guangzhou, China. Land Use Policy, 29, 464-472. http://dx.doi.org/10.1016/j.landusepol.2011.09.005

Grant, C. J. (1973). Acid sulphate soils in Hong Kong. In: Dost, H. (ed.), Proceeding International Symposium of Acid Sulfate Soils. ILRI Publication 18. International Institute for Land Reclamation and Improvement, Wageningen. pp. 215-228. 
Hajek, B. F., \& Boyd, C.E. (1994). Rating soil and water information for aquaculture. Aquacultural Engineering, 13, 115-128. http://dx.doi.org/10.1016/0144-8609(94)90009-4

Halder, J. C. (2013). Land suitability assessment for crop cultivation by using remote sensing and GIS. Journal of Geography and Geology, 5(3), 65-74. http://dx.doi.org/10.5539/jgg.v5n3p65

Hasnawi, \& Mustafa, A. (2010). Characteristics, suitability and management of land for brackishwater ponds in North Luwu Regency, South Sulawesi Province. Jurnal Riset Akuakultur, 5(3), 449-463.

Hazelton, P., \& Murphy, B. (2009). Interpreting Soil Test Results: What do All the Numbers Mean? CSIRO Publishing, Collingwood. 152 pp.

Ilyas, S., Cholik, F., Poernomo, A., Ismail, W., Arifudin, R., Daulay, T., Ismail, A., Koesoemadinata, S., Rabegnatar, INS, Soepriyadi, H., Suharto, H., Azwar, Z. I., \& Ekowardoyo, S. (1987). Petunjuk teknis bagi pengoperasian unit usaha pembesaran udang windu. Pusat Penelitian dan Pengembangan Perikanan, Jakarta. $100 \mathrm{hlm}$.

Kementrian Negara Lingkungan Hidup. (2004). Keputusan Menteri Negara Lingkungan Hidup Nomor 51 tahun 2004 tentang Baku Mutu Air Laut.Jakarta : KLH.

Kusumastanto. (2003). Ocean policy dalam membangun negeri bahari diera otonomi daerah. PT. Gramedia Pustaka Utama. Jakarta.

Melville, M. D. (1993). Soil Laboratory Manual. School of Geography, The University of New South Wales, Sydney. 74 pp.

Menon, R. G. (1973). Soil and Water Analysis: A Laboratory Manual for the Analysis of Soil and Water. Proyek Survey O.K.T. Sumatera Selatan, Palembang. 190 pp.

Mustafa A, \& Rachmansyah. (2008). Pengelolaan lahan tambak di Kabupaten Pinrang, Provinsi Sulawesi Selatan. Balai Riset Perikanan Budidaya Air Payau Maros. 27 hal.

Pantjara, B., \& Sahib, M. (2008). Aplikasi pupuk berimbang terhadap pertumbuhan rumput laut Gracillaria verucosa di tambak tanah sulfat masam. Balai Riset Perikanan Budidaya Air Payau Maros. 13 hal.

Poernomo, A. (1992). Pemilihan lokasi tambak udang berwawasan lingkungan. Pusat Penelitian dan Pengembangan Perikanan, Jakarta. 40 hlm.

Rukyani, A. (2001). Kebijakan penerapan teknologi budidaya udang windu yang bertanggungjawab. Pusat Riset Perikanan Budidaya-Departemen Kelautan dan Perikanan. Jakarta. Hal 35 - 54.

Soewardi, K. (2002). Pengelolaan kualitas air tambak. Makalah dalam seminar penetapan standar kualitas air buangan tambak. Ditjen Perikanan Budidaya, 7 - 9 Agustus 2002.

Soewardi, K. (2007). Pengelolaan budidaya tambak berkelanjutan. Materi Kuliah PS-SPL, IPB. Tidak dipublikasikan. 


\section{Macrothink}

Soil Survey Staff. (2001). Soil Taxonomy, a Basic System of Soil Classification for Making and Interpreting Soil Survey. United State Department of Agriculture,Washington,DC.734 pp.

Sulaeman, S., \& Eviati. (2005). Technical Guidelines for Chemical Analysis of Soil, Plant, Water, and Fertilizer. Edited by: Prasetyo, B.H., Santoso, D. and Widowati, L.R. Research Institute for Soil, Bogor. 136 pp.

Taslihan, (2003). Budidaya udang bertanggungjawab.Balai Besar Riset Perikanan Budidaya Air Payau Jepara.

Tuhri, M. (2000). Tata ruang kawasan Pesisir, Infrasturktur, Serta Peluang Pendapatan asli daerah. Paper disampaikan Pada Workshop Bisnis Budidaya udang berke-lanjutan. Bogor 27-29 September 2000. 8 halaman.

Widigdo B, \& Kadarwan S. (2002). Rumusan kriteria ekobiologis untuk menentukan potensi alami kawasan pesisir untuk budidaya tambak. Diktat Bahan Kuliah Pengembangan Perikanan Kawasan Pesisir dan Laut. Institut Pertanian Bogor. 32 Hal.

Widigdo B. (2002). Perkembangan dan peranan perikanan budidaya dalam pembangunan. Makalah dalam seminar penetapan standar kualitas air buangan tambak, Ditjen Perikanan Budidaya, Puncak 7 - 9 Agustus 2002.

\section{Copyright Disclaimer}

Copyright for this article is retained by the author(s), with first publication rights granted to the journal.

This is an open-access article distributed under the terms and conditions of the Creative Commons Attribution license (http://creativecommons.org/licenses/by/3.0/). 